\title{
FACTORS AFFECTING THE POLLUTION OF THE TAPIN RIVER AND ITS STRATEGIES IN TAPIN DISTRICT OF SOUTH KALIMANTAN PROVINCE, INDONESIA
}

\author{
Noor Anna \\ Master's Study Program of Natural Resource Management and Environment, \\ Faculty of Fisheries and Marine Science, University of Lambung Mangkurat, \\ Banjarbaru, Indonesia \\ E-mail: nooranna.hc03@gmail.com
}

\begin{abstract}
This article aims to determine the effect of liquid waste, knowledge, and community actions on Tapin River pollution in Tapin Regency, South Kalimantan Province, and river management strategies to reduce Tapin River pollution that can be done by improving actions. This study uses quantitative research and qualitative research using a crosssectional. Collecting data using a questionnaire that was analyzed using the Regression test. The results showed that waste, liquid waste, knowledge, and community actions in maintaining river cleanliness had a significant effect on Tapin river pollution in Tapin Regency, South Kalimantan Province (Fcount(220.431) > Ftable (2.720) or Sig. $=0.000<0.05$ ). Liquid waste has a significant effect on the pollution of the Tapin river (tcount $(2.684)>$ ttable $(1.664)$ or $\mathrm{sig}=0.009<0.05)$. The knowledge of the community in maintaining the cleanliness of the river has a significant effect on the pollution of the Tapin river ( $t$ count $(4,197)>t$ table $(1,664)$ or sig $=0.000<0.05)$ and community actions in maintaining the cleanliness of the river have a significant effect on the pollution of the Tapin river ( $t$ count $(5,484)>t$ table $(1.664)$ or $s i g=0.000<0.05)$. The results of the determination test show that the community's actions in maintaining the cleanliness of the river have a Beta coefficient value of 0.345 (34.5\%), community knowledge in maintaining river cleanliness has a Beta coefficient value of $0.281(28.1 \%)$, and liquid waste has a Beta coefficient value of $0.140(14 \%)$. The river management strategy to reduce the pollution of the Tapin River that can be done is by improving community actions so as not to litter and increasing public knowledge about good and correct waste management. For communities along the Tapin River, Tapin Regency, it can be used as additional information to find out how to clean the river and reduce river pollution, which plays an important role in the health of the river border community and good use of the river.
\end{abstract}

\section{KEY WORDS}

Waste, knowledge, action, river pollution.

Water is one of the environmental components that is severely damaged by pollution, so it is used as one of the indicators of the environmental status of a region and national (Yuliastuti et al., 2011). These pollutants can come from domestic activities (households), settlements, cities, markets, roads, non-domestic sources (factories, industries, agriculture, livestock, fisheries, mining), and many other sources that enter water bodies. These pollutants affect water quality for drinking, industrial, and other purposes either directly or indirectly. Water sources that are of great concern to water pollution are surface water or river water. The quality of river water is influenced by the quality of the water supply coming from the catchment area(Wilk et al., 2018), while the quality of the water supply from the catchment area is related to the human activities in it (Sri Wahyu Kusumastuti et al., 2021). Water is a fundamental natural resource and a strategic economic resource and an indispensable necessity for human survival and social development.

In recent years, water pollution remains a challenging problem in the world and can threaten the sustainability of urban systems (Mishra et al., 2017). The use of resources for development always involves pollution. An environment can be said to be polluted if it can be invaded by polluters or disturbed by living creatures that attack(Soemarwoto, 2019). For 
example, River pollution can be caused by high levels of sideman by erosion, the rapid growth of compounds produced from human, animal, and plant organic waste, and industrial waste treatment activities. The river is a source of surface water that is beneficial for human life. The movement of water downstream from the springs across the channels of various rivers occurs dynamically. It depends on the dynamics, seasons, land use, and lifestyle of the surrounding community(Hendrawan, 2010)

The South Kalimantan province of Indonesia is nicknamed the city of a thousand rivers. This fits the natural conditions of South Kalimantan which are flowed by rivers. The river becomes a very important role for this area. Tapin Regency is one of the regencies that has the largest river in South Kalimantan Province. 3 rivers are flowing through Tapin Regency, namely Tapin River, Nagara River, and Binuang River. The area of Tapin Regency is 2,174.95 km2, most of Tapin Regency is dominated by residential areas, most of which are located on the Tapin river border. The Tapin River itself flows into 5 sub-districts, namely Piani District, Bungur District, North Tapin District, Bakarangan District, Candi Laras Selatan District. Based on data from the Tapin Regency Environmental Service, the status of Tapin river water quality in 2020 is in a mild to moderately polluted state(|iii -, nd).

The upstream of the Tapin River is one of the areas traversed by high mining activity and liquid waste from coal mining discharged into the Tapin River, while on the river bank there are many houses with a total number of 490 households, where some community activities use the river for bathing, washing, and cleaning. some people have a lack of awareness about maintaining the cleanliness of the river where plastic waste, baby diaper waste, animal feed waste, plantation and agricultural waste, household waste and so on can disrupt the balance of ecosystems and river habitats and have a bad impact on the population who work as a fisherman because the catch is no longer sufficient for daily needs. There are even some fish species such as shrimp that are started rarely to be found. Changes in people's consumption patterns occur due to the increasing population and the rate of urban development. Activities carried out by households, agriculture and industry certainly cause pollution which has an impact on decreasing river quality. Several factors that can affect river water pollution include trash, wastewater, knowledge, and community actions. This is in accordance with the monitoring of the Ministry of Environment of the Republic of Indonesia (LH RI) in 2020, as many as $75 \%$ of rivers in Indonesia are heavily polluted due to waste disposal and household and industrial wastewater, lack of public knowledge and community actions that violate government regulations in managing trash and waste.

The characteristics of the landscape in this area consist of the Barito Watershed (DAS). Of course, this harms the environment as a result of human activities living on it. Most of the people who live on the border of the Tapin river have latrines whose waste is directly discharged into the river, not through WWTPs. This can cause river pollution. People in Tapin Regency, which is located on the Tapin River border, also carry out agricultural activities and still use fertilizers that are not environmentally friendly. Seepage from the use of fertilizers that are not environmentally friendly can seep into rivers and pollute them. The existence of coal mining activities that pass through the Tapin river basin also produces liquid waste which is discharged into the Tapin River.

\section{RESULTS AND DISCUSSION}

This research was conducted in Tapin Regency, South Kalimantan Province. Based on the field observations, it is known that the Tapin River is located in 5 districts. The research method used is a research method combining two research methods at once, namely qualitative and quantitative research activity, so the data that will be obtained will be more comprehensive, valid, reliable, and objective. The approach used in this study is a crosssectional paradigm. Cross-sectional is research to study the correlation between risk factors by approach or data collection at one time only. 
Multiple linear regression analysis was used to determine whether there was an effect of waste (X1), liquid waste (X2), knowledge (X3), and actions (X4) that had a significant effect on the pollution of the Tapin River $(Y)$ in Tapin Regency, South Kalimantan Province.

Tapin Regency with an area of $2,174.95 \mathrm{Km}^{2}$ is one of the regencies in the South Kalimantan Province. Geographically, Tapin Regency is located between 20.32'43"-30.00'43" South Latitude and 1140.46'13"-1150.30'33" East Longitude.

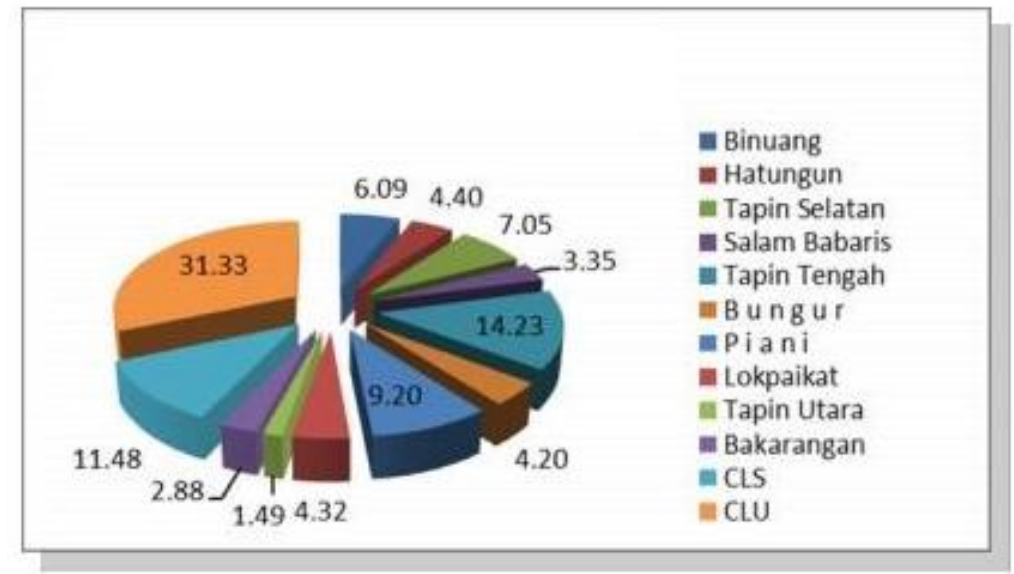

Figure 1 - Population Data 2020 (Source: Tapin Regency in 2021 Figures)

Geologically, Tapin Regency consists of highland and mountainous land that extends from east to south. From north to the west there are mostly lowlands (swamps). The main rock types in the Tapin area are quarter-aged rocks. The area that has this type of rock is almost the entire area, which is about $80.01 \%$ of the total area. In addition to the rock types of quarter-age, a small part of the Tapin area has Mesozoic age rocks. The area with these rocks is in the Districts of Binuang and Piani. Most of the Tapin area is located at an altitude of lower than $500 \mathrm{~m}$ above sea level. This condition implies that the altitude factor is not an obstacle in developing this area in the agricultural sector. Areas with an altitude of more than $500 \mathrm{~m}$ above sea level are only found in a small part of the Piani District.

Types of soil in Tapin Regency consist of organosol gleyhumus, $73.50 \%$, mostly located in the Districts of Candi Laras Utara, Candi Laras Selatan, Binuang, Tapin Selatan, and Tapin Tengah; red and yellow podzolic, $18.23 \%$, mostly located in the Districts of Piani, Bungur, Tapin Selatan and Lokpaikat; alluvial, by $5.7 \%$ mostly located in the Districts of Binuang, South Tapin, Lokpaikat, and North Tapin; and the $2,57 \%$ red and yellow podzolic complex, Litosol, Latosol located in Piani District. Based on geomorphological aspects, it is divided into 3 original form units and 3 landforms, namely: denudational origin formation (D) consisting of strongly eroded hilly landform units (D1) fluvial origin formation (F) consisting of former swampy plains form units (F1), and the structural origin formation (S) consists of a weak undulating hilly landform unit (S1). So many rivers flow through the area.

Rivers are a part of the earth's surface which, by its nature, becomes a place for water to flow. It can be concluded that the river is part of the land that is the place where water flows from springs or rainfall. The river is divided into three parts, namely the upstream, middle, and downstream areas. The upstream part of the river is the spring area of the river itself. The upstream of the river is usually a highland area that is prone to erosion, the upstream substrate is sand and rocks and the group of animals that are often encountered is Coarse Particulate Organic Matter (CPOM) animals such as the abundance of shredders. The middle stream is a transitional area between the upstream and downstream rivers. (Louhi et al., 2010).

Rivers are sources of surface water that provide benefits for human life. The movement of water downstream from the shower across the various streams occurs dynamically. These driving forces depend on the seasons, land use, and patterns of human life in the vicinity. 
(Zhang et al., 2018). This situation can cause changes in the quantity and quality of water based on the development of the river environment and human life(Angello et al., 2021).

The river border is between the river ecosystem and the land ecosystem. The river border includes the space on the left and right of the riverbed between the borderline and the edge of the riverbed for unbanked rivers or between the borderline and the outer edge of the embankment rivers. The border area includes the riverbank area, which is part of the river body that is only flooded during the rainy season, and the border area outside the bank, which is an area that accommodates overflowing river water in the rainy season and has higher soil moisture than soil moisture in terrestrial ecosystems. (Poedjioetami, 2008).

Based on the results of the questionnaire regarding Respondents' Responses about Tapin River Trash in Tapin Regency, South Kalimantan Province (X1), it can be seen in the following table:

Table 1 - Respondents' Responses about Tapin River Trash in Tapin Regency, South Kalimantan Province (X1)

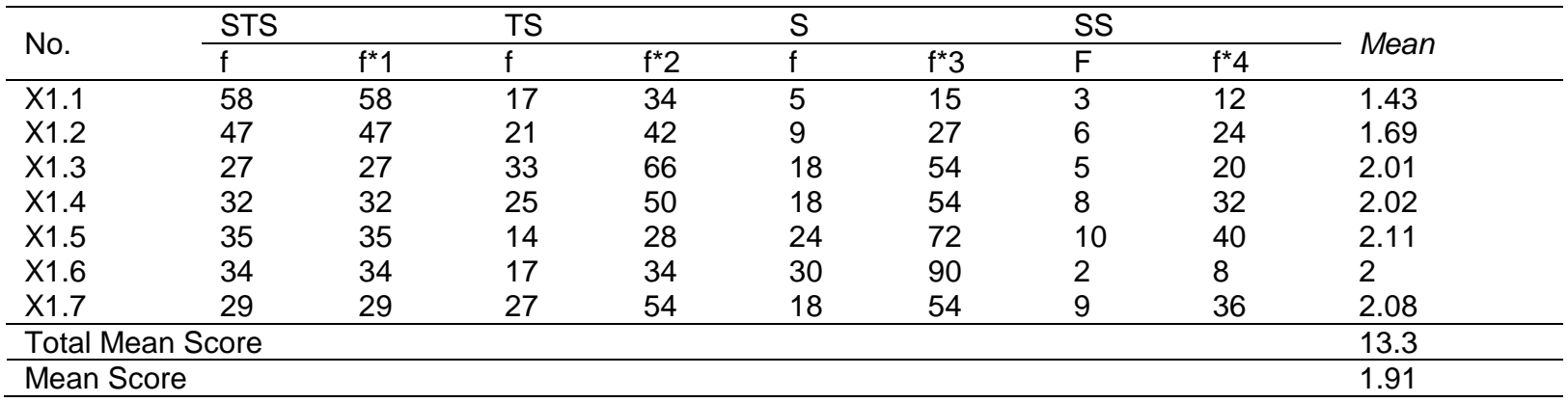

Based on the results of the questionnaire regarding Respondents' Responses about Tapin River Liquid Waste in Tapin Regency, South Kalimantan Province (X2), it can be seen in the following table:

Table 2 - Respondents' Responses about Tapin's River Liquid Waste in Tapin Regency, South Kalimantan Province (X2)

\begin{tabular}{|c|c|c|c|c|c|c|c|c|c|}
\hline \multirow{2}{*}{ No. } & \multicolumn{2}{|c|}{ STS } & \multicolumn{2}{|l|}{ TS } & \multicolumn{2}{|l|}{$\mathrm{S}$} & \multicolumn{2}{|c|}{ SS } & \multirow{2}{*}{ Mean } \\
\hline & $f$ & $f^{*} 1$ & $f$ & $f^{\star} 2$ & $f$ & $f * 3$ & $f$ & $f^{\star} 4$ & \\
\hline $\mathrm{X} 2.1$ & 21 & 21 & 5 & 10 & 53 & 159 & 4 & 16 & 2.48 \\
\hline $\mathrm{X} 2.2$ & 37 & 37 & 21 & 42 & 19 & 57 & 6 & 24 & 1.93 \\
\hline $\mathrm{X} 2.3$ & 29 & 29 & 26 & 52 & 20 & 60 & 8 & 32 & 2.08 \\
\hline$X 2.4$ & 40 & 40 & 12 & 24 & 21 & 63 & 10 & 40 & 2.01 \\
\hline $\mathrm{X} 2.5$ & 33 & 33 & 17 & 34 & 31 & 93 & 2 & 8 & 2.02 \\
\hline \multicolumn{5}{|c|}{ Total Mean Score } & & & & & 10.5 \\
\hline \multicolumn{5}{|c|}{ Mean Score } & & & & & 2.11 \\
\hline
\end{tabular}

Based on the results of the questionnaire regarding Respondents' Responses about Community Knowledge in Maintaining River Cleanliness (X3), it can be seen in the following table:

Table 3 - Respondents' Responses about Community Knowledge in Keeping the River Clean (X3)

\begin{tabular}{|c|c|c|c|c|c|c|c|c|c|}
\hline \multirow{2}{*}{ No. } & \multicolumn{2}{|c|}{ STS } & \multicolumn{2}{|l|}{ TS } & \multicolumn{2}{|l|}{ S } & \multicolumn{2}{|c|}{ SS } & \multirow{2}{*}{ mean } \\
\hline & $f$ & $f^{*} 1$ & $f$ & $f^{\star} 2$ & $f$ & $f * 3$ & $f$ & $f^{*} 4$ & \\
\hline$\overline{X 3.1}$ & 31 & 31 & 25 & 50 & 19 & 57 & 8 & 32 & 2.05 \\
\hline X3.2 & 37 & 37 & 12 & 24 & 24 & 72 & 10 & 40 & 2.08 \\
\hline X3.3 & 33 & 33 & 17 & 34 & 31 & 93 & 2 & 8 & 2.02 \\
\hline X3.4 & 29 & 29 & 27 & 54 & 18 & 54 & 9 & 36 & 2.08 \\
\hline X3.5 & 39 & 39 & 18 & 36 & 18 & 54 & 8 & 32 & 1.94 \\
\hline X3.6 & 27 & 27 & 33 & 66 & 19 & 57 & 4 & 16 & 2 \\
\hline X3.7 & 34 & 34 & 20 & 40 & 28 & 84 & 1 & 4 & 1.95 \\
\hline \multicolumn{5}{|c|}{ Total Mean Score } & & & & & 14.1 \\
\hline \multicolumn{5}{|c|}{ Mean Score } & & & & & 2.02 \\
\hline
\end{tabular}


Based on the results of the questionnaire regarding Respondents' Responses about Community Actions in Keeping River Clean (X4), it can be seen in the following table:

Table 4 - Respondents' Responses about Community Action in Keeping the River Clean (X4)

\begin{tabular}{|c|c|c|c|c|c|c|c|c|c|}
\hline \multirow[b]{2}{*}{ No. } & \multicolumn{2}{|c|}{ STS } & \multicolumn{2}{|l|}{ TS } & \multicolumn{2}{|l|}{$\mathrm{S}$} & \multicolumn{2}{|c|}{ SS } & \multirow[b]{2}{*}{ mean } \\
\hline & $f$ & $f^{*} 1$ & $f$ & $f^{*} 2$ & $f$ & $f^{*} 3$ & $f$ & $f^{*} 4$ & \\
\hline $\mathrm{X} 4.1$ & 34 & 34 & 17 & 34 & 30 & 90 & 2 & 8 & 2 \\
\hline$X 4.2$ & 29 & 29 & 26 & 52 & 18 & 54 & 10 & 40 & 2.11 \\
\hline$X 4.3$ & 39 & 39 & 18 & 36 & 18 & 54 & 8 & 32 & 1.94 \\
\hline X4.4 & 59 & 59 & 17 & 34 & 6 & 18 & 1 & 4 & 1.39 \\
\hline X4.5 & 40 & 40 & 12 & 24 & 21 & 63 & 10 & 40 & 2.01 \\
\hline X4.6 & 33 & 33 & 17 & 34 & 31 & 93 & 2 & 8 & 2.02 \\
\hline \multicolumn{5}{|c|}{ Total Mean Score } & & & & & 11.5 \\
\hline \multicolumn{5}{|c|}{ Mean Score } & & & & & 1.64 \\
\hline
\end{tabular}

Based on the results of the questionnaire regarding Respondents' Responses about Tapin River Pollution in Tapin Regency, South Kalimantan Province (Y), then it can be seen in the following table:

Table 5 - Respondents' Responses about Tapin River Pollution in Tapin Regency, South Kalimantan Province $(\mathrm{Y})$

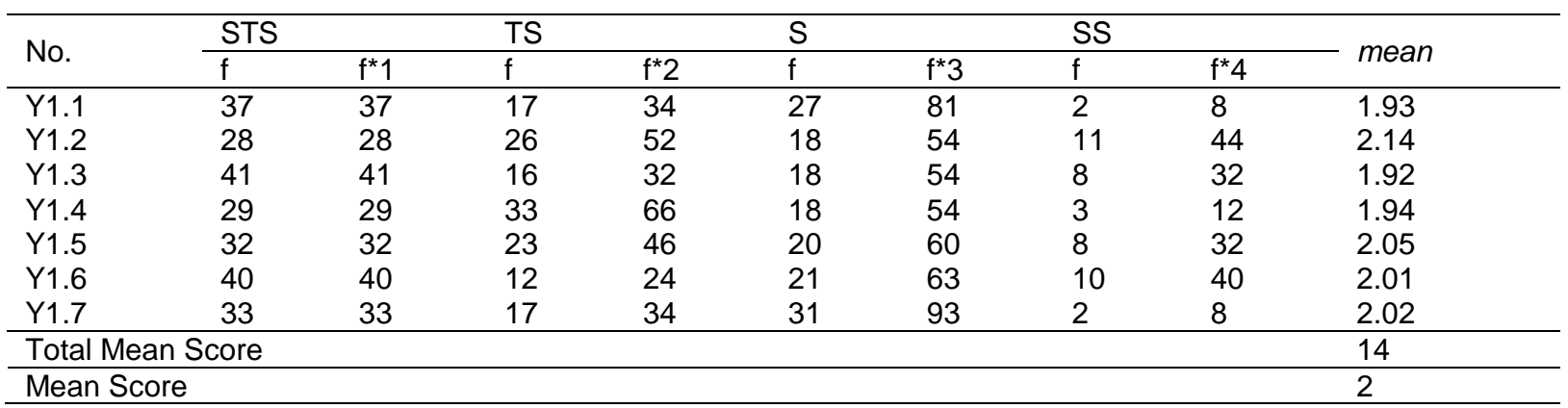

Based on these data, regression analysis was carried out multiple linear with considerations: (1) independent variable $(X)$ more than 1 variable, (2) data scale is ordinal, (3) there is a causal relationship between the independent variable $(X)$ to the dependent variable $(Y)$. This analysis is used to determine the direction of the relationship between the independent variable and the dependent variable whether the independent variable is positively or negatively related.

Table 6 - Summary of Multiple Regression Analysis Results

\begin{tabular}{|c|c|c|c|c|c|}
\hline $\begin{array}{l}\text { Dependent } \\
\text { variable }\end{array}$ & Independent Variable & B & tcount & Sig & Significant/not \\
\hline \multirow{4}{*}{$\begin{array}{l}\text { Tapin River } \\
\text { Pollution } \\
\text { (Y) }\end{array}$} & $\begin{array}{l}\text { Trash } \\
(\mathrm{X} 1)\end{array}$ & 0.371 & 5,401 & 0.000 & Significant \\
\hline & $\begin{array}{l}\text { Liquid waste } \\
\text { (X2) }\end{array}$ & 0.172 & 2,684 & 0.009 & Significant \\
\hline & $\begin{array}{l}\text { Knowledge } \\
\text { The community in maintaining the cleanliness } \\
\text { of the river } \\
\text { (X3) }\end{array}$ & 0.339 & 4,197 & 0.000 & Significant \\
\hline & $\begin{array}{l}\text { Community Actions in Maintaining River } \\
\text { Cleanliness } \\
\text { (X4) }\end{array}$ & 0.385 & 5,484 & 0.000 & Significant \\
\hline \multicolumn{4}{|c|}{$\begin{array}{l}\mathrm{a}(\text { Constant })=-1.974 \\
\mathrm{R}=0.959 \\
\mathrm{R} \text { Square }=0.919 \\
\text { Adjusted } \mathrm{R} \text { Square }=0.915 \\
\mathrm{SEE}=1.035\end{array}$} & \multicolumn{2}{|c|}{$\begin{array}{l}\text { Fcount }=220.431 \\
\text { Sig } F=0.000 \\
F \text { table }=2,720 \\
\text { ttable }=1.664\end{array}$} \\
\hline
\end{tabular}


From these data it can be interpreted that river pollution with the variables of trash, liquid waste, knowledge, and action is $-1,974$ has a significant effect, meaning that it starts from a negative point or river pollution before the research was carried out, there had been pollution of the Tapin river in Tapin Regency, South Kalimantan Province. A constant of 1.974 means that if the trash, liquid waste, knowledge, and there is no community action in maintaining the cleanliness of the river or the value is 0 , then the value of pollution of the Tapin river in Tapin Regency, South Kalimantan Province is a (constant) $=-1.974$. The graph of statistical test results can be seen in the following figure:

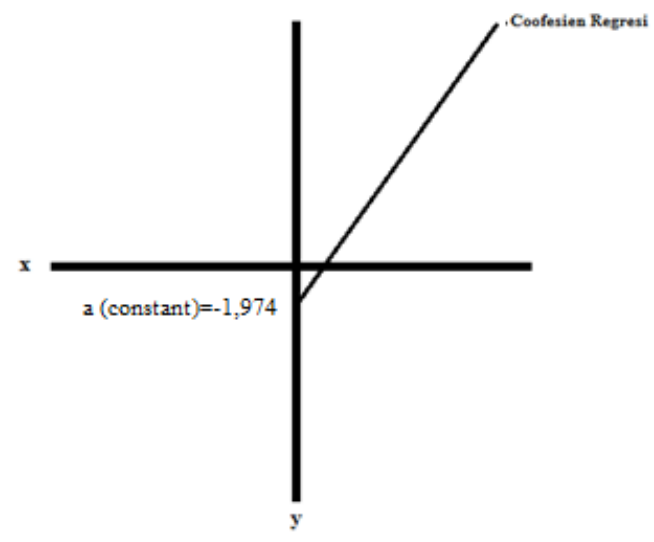

Figure 2 - Regression Test Graph

Based on the results of the multiple regression analysis in Table 6 , the multiple regression equation models can be written as follows:

$$
Y=-1.974+0.371(X 1)+0.172(X 2)+0.339(X 3)+0.385(X 4)+e
$$

Test result against $X 1$ (trash) shows t count of 5,401 with a significance level is $99 \%$. This means that trash has a very significant effect on river pollution. This is because the regression coefficient of the waste variable of 0.371 is positive, meaning that between waste and river pollution there is a positive relationship or a straight relationship, if there is an increase in the volume of trash by $1 \mathrm{~kg}$, it will result in a river flow of $0.371 \mathrm{~kg}$. This is because people who are on the border of the Tapin river still throw the trash into the river

The results of the test on liquid waste (X2) show a t-count of 2,684 with a significant level of $99 \%$ This means that liquid waste has a very significant effect on river pollution. This is because the liquid waste variable regression coefficient of 0.172 is positive, meaning that between liquid waste and river pollution there is a positive relationship or a straight relationship, if there is an increase in the volume of liquid waste by 1 liter it will result in river pollution of 0.371 liters. This is based on observations in the field that people living on riverbanks still carry out MCK activities in rivers and have not managed the disposal of liquid waste properly or have not used IPAL.

The test results on knowledge (X3) show t count of 4.197 with a significant level of $99 \%$ meaning that knowledge has a significant effect on river pollution. This is because the variable regression coefficient knowledge in maintaining river cleanliness of 0.339 is positive, meaning that between knowledge in maintaining river cleanliness and river pollution has a positive relationship or a straight relationship. If there is an increase in the volume of knowledge in maintaining river cleanliness by 1 time it will result in river pollution of 0.371 times. This is due to the lack of knowledge of the people on the river border on proper waste management.

The test results on the action (X4) show t count of 5.484 with a significant level of $99 \%$ meaning that the action has a significant effect on river pollution. This is due to the variable regression coefficient action of 0.385 is positive, meaning that between actions in maintaining river cleanliness and river pollution has a positive relationship or a straight 
relationship. If there is an increase in the volume of action in maintaining river cleanliness by 1 time it will result in river pollution of 0.371 times. This is because the actions of the people living on the Tapin river border are still less responsive or less concerned about river pollution.

The results of the regression coefficient research can be interpreted that river pollution with trash, liquid waste, knowledge, and action variables is -1.974 meaning that the constant is not equal to 0 or the regression line does not pass through the center point / point 0 . This means that before the research was carried out river pollution had occurred Tapin in Tapin Regency, South Kalimantan Province. A constant of -1.974 means that if there is no trash, liquid waste, knowledge, and community actions in maintaining the cleanliness of the river or the value is 0 , then the pollution of the Tapin river in Tapin Regency, South Kalimantan Province, the value is a (constant) $=-1.974$. This means that if it is added with factors that affect pollution, the value of pollution will increase.

Based on the results of the determinant test can be seen in the following table:

Table 7 - Test of Determinants

\begin{tabular}{lllc}
\hline No. & Rating & Variable & Beta Coefficient \\
\hline 1 & 2 & Trash (X1) & 0.294 \\
2 & 4 & Liquid Waste (X2) & 0.140 \\
3 & 3 & Community Knowledge in Maintaining River Cleanliness (X3) & 0.281 \\
4 & 1 & Community Actions in Maintaining River Cleanliness (X4) & 0.345 \\
\hline
\end{tabular}

So it can be concluded that the community's actions in maintaining the cleanliness of the river have a Beta Coefficient value of 0.345 which means that it has the greatest influence on pollution of the Tapin River in Tapin Regency, South Kalimantan Province, trash has a Beta Coefficient value of 0.294 which means it has the second largest influence in pollution of the Tapin River in Tapin Regency, South Kalimantan Province, community knowledge in maintaining the cleanliness of the river has a Beta Coefficient value of 0.281 which means it has the third largest influence in pollution of the Tapin River in Tapin Regency, South Kalimantan Province and liquid waste has a Beta Coefficient value of 0.140 which means it has the fourth largest influence in pollution of the Tapin River in Tapin Regency, South Kalimantan Province.

\section{CONCLUSION}

The results of the study show that trash, liquid waste, knowledge, and community actions in maintaining river cleanliness have a significant effect by $99 \%$. Trash has a significant effect on the pollution of the Tapin river by $99 \%$. Liquid waste has a significant effect on the pollution of the Tapin river by $99 \%$. The knowledge of the community in maintaining the cleanliness of the river has a significant effect on the pollution of the Tapin river by $99 \%$ and community actions in maintaining the cleanliness of the river have a significant effect on the pollution of the Tapin river by $99 \%$. The results of the determination test show that the community's actions in maintaining the cleanliness of the river (X4) have a Beta coefficient value of 0.345 (34.5\%), trash (X1) has a Beta Coefficient value of 0.294 (29.4\%), community knowledge in maintaining river cleanliness (X3) has a Beta coefficient value of $0.281(28.1 \%)$ and liquid waste (X2) has a Beta coefficient value of $0.140(14 \%)$. The river management strategy to reduce the pollution of the Tapin River that can be done is by improving community actions so as not to litter and increasing public knowledge about good and correct waste management.

\section{REFERENCES}

1. |iii -, L. A. (n.d.). Penyusunan RPIJM Kabupaten Tapin 2016-2020.

2. Angello, Z. A., Behailu, B. M., \& Tränckner, J. (2021). Selection of optimum pollution load reduction and water quality improvement approaches using scenario basedwater 
quality modeling in little akaki river, Ethiopia. Water (Switzerland), 13(5), 584. https://doi.org/10.3390/w13050584.

3. Hendrawan, D. (2010). Kualitas Air Sungai dan Situ di DKI Jakarta. MAKARA of Technology Series. https://doi.org/10.7454/mst.v9i1.315.

4. Louhi, K. R., Karvonen, A., Rellstab, C., \& Jokela, J. (2010). Is the population genetic structure of complex life cycle parasites determined by the geographic range of the most motile host? Infection, Genetics and Evolution, 10(8), 1271-1277. https://doi.org/10.1016/j.meegid.2010.08.013.

5. Mishra, B. K., Regmi, R. K., Masago, Y., Fukushi, K., Kumar, P., \& Saraswat, C. (2017). Assessment of Bagmati river pollution in Kathmandu Valley: Scenario-based modeling and analysis for sustainable urban development. In Sustainability of Water Quality and Ecology (Vols. 9-10, pp. 67-77). https://doi.org/10.1016/j.swaqe.2017.06.001

6. Poedjioetami, E. (2008). Penataan Ulang Kawasan Bantaran Sungai Dengan Menghadirkan Sentra Ekonomi dan Rekreasi Kota. Jurnal Rekayasa Perencanaan, 4(3).

7. Soemarwoto, O. (2019). Analisis Mengenai Dampak Lingkungan. Sustainability (Switzerland), 11(1), 1-14. http://scioteca.caf.com/bitstream/handle/123456789/1091/RED2017-Eng 8ene.pdf?sequence=12\&isAllowed=y\%0Ahttp://dx.doi.org/10.1016/j.regsciurbeco.2008.0 6.005\%0Ahttps://www.researchgate.net/publication/305320484_SISTEM_PEMBETUNG AN_TERPUSAT_STRATEGI_MELESTARI.

8. Sri Wahyu Kusumastuti, A., Moh Bisri, B., Solichin, C., \& Tri Budi P, D. (2021). Water Quality Monitoring and Evaluation in the Bengawan Solo River Region. IOP Conference Series: Earth and Environmental Science, 641(1), 012024. https://doi.org/10.1088/17551315/641/1/012024.

9. Wilk, P., Orlinska-Wozniak, P., \& Gebala, J. (2018). The river absorption capacity determination as a tool to evaluate state of surface water. Hydrology and Earth System Sciences, 22(2), 1033-1050. https://doi.org/10.5194/hess-22-1033-2018.

10. Yuliastuti, E., Sasongko, S. B., \& Nugraha, W. D. (2011). Evaluasi Kualitas Air Sungai Ngringo Kabupaten Karanganyar dalam upaya Pengendalian Pencemaran Perairan. Prosiding Seminar Rekayasa Dan Proses, I(02), 1-6.

11. Zhang, H., Jin, G., \& Yu, Y. (2018). Review of river basinwater resource management in China. Water (Switzerland), 10(4), 425. https://doi.org/10.3390/w10040425. 